\title{
Acceptance of COVID-19 vaccination and correlated variables among global populations: A systematic review and meta-analysis
}

\author{
Ricvan Dana Nindrea ${ }^{\mathrm{a}, *}$, Elly Usman $^{\mathrm{b}}$, Yusticia Katar ${ }^{\mathrm{b}}$, Nissa Prima Sari ${ }^{\mathrm{c}}$ \\ ${ }^{a}$ Department of Public Health and Community Medicine, Faculty of Medicine, Universitas Andalas, Padang, 25127, Indonesia \\ ${ }^{\mathrm{b}}$ Department of Pharmacology, Faculty of Medicine, Universitas Andalas, Padang, 25127, Indonesia

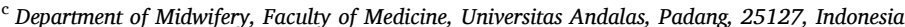

A R T I C L E I N F O

\section{Keywords:}

Acceptance

COVID-19

Risk factors

Vaccine

\begin{abstract}
A B S T R A C T
Introduction: The most awaited solution is an efficient COVID-19 vaccine. COVID-19 vaccine acceptance has not been studied in a meta-analysis. The objective of this research was to find the acceptance of COVID-19 vaccination and correlated variables.

Methods: A systematic review of studies on acceptance of COVID-19 vaccination and correlated variables in the ProQuest, PubMed, and EBSCO to find relevant articles published between January 2020 and March 2021. Using fixed and random-effect models, the risk factors Pooled Odds Ratio (POR) were measured. The heterogeneity was calculated using the I-squared formula. Egger's and Begg's tests were utilised to determine publication bias. STATA 16.0 was used for all data processing and analysis.

Results: This study results showed the related factors for COVID-19 vaccination acceptance, high income has the highest odd ratio (POR $=2.36$ ), followed by encountered with COVID-19 (POR = 2.34), fear about COVID-19 $(\mathrm{POR}=2.07)$, perceived benefits (POR $=1.81)$, flu vaccine during the previous season $(\mathrm{POR}=1.69)$, healtcare workers (POR $=1.62)$, male (POR $=1.61)$, married (POR $=1.59)$, perceived risk $(\mathrm{POR}=1.52)$, trust in health system $(\mathrm{POR}=1.52)$, chronic diseases $(\mathrm{POR}=1.47)$, high education $(\mathrm{POR}=1.46)$, high level of knowledge $(\mathrm{POR}=1.39)$, female $(1.39)$, and older age (POR $=1.07)$. The heterogeneity calculation showed homogenous among studies in high income, fear about COVID-19, healthcare workers, married, chronic diseases, and female $\left(\mathrm{I}^{2} \leq 50 \%\right)$. For the studies included in this review, there was no apparent publication bias. Conclusion: The analysis of this review may be useful to the nation in determining the best method for implementing COVID-19 mass vaccination programs based on relevant factors that influence vaccine acceptance.
\end{abstract}

\section{Introduction}

Since 2020, COVID-19 widespread has become a serious community health concern. The COVID-19 emergency afflicted many nations. By March 2021, there had been over 128.2 million confirmed cases of the disease, with 2.8 million deaths.

COVID-19 not only has a major health effect, but it also has a significant economic impact that should not be ignored. It has resulted in a major decline in workforces and an increase in jobless around the world. ${ }^{2}$ These negative consequences have prompted pharmaceutical firms to produce a vaccine as soon as possible. At the end of 2020 , multiple vaccines to prevent COVID-19 infection were approved. and there were more than fifty COVID-19 vaccine potential in production. ${ }^{3}$ Vaccination programs have started in a number of countries around the world. ${ }^{4}$ Despite this, people continue to have concerns about vaccine safety and effectiveness, including the durability of COVID-19 defense, as many cases of reinfection have been documented. ${ }^{5,6}$ Furthermore, the rapid production of vaccines raises concerns about their efficacy. Vaccine production has historically been connected to harmful effects. ${ }^{7}$

For decades, vaccines have proven to be an effective means of disease prevention. ${ }^{8}$ Vaccine hesitancy and refusal, on the other hand, are major issues around the world, causing the World Health Organization (WHO) to name this confusion as one of the top ten health risks for $2019 .{ }^{9}$ Vaccine apprehension has been linked to religious values, personal

\footnotetext{
* Corresponding author. Department of Public Health and Community Medicine, Faculty of Medicine, Universitas Andalas, Main Campus at Limau Manis, Gedung A 1st Floor, Pauh, Padang, 25166, West Sumatra, Indonesia.

E-mail addresses: Ricvan@med.unand.ac.id (R.D. Nindrea), ellyusman@med.unand.ac.id (E. Usman), yusticiakatar@yahoo.com (Y. Katar), nissaprimasari@ gmail.com (N.P. Sari).
} 


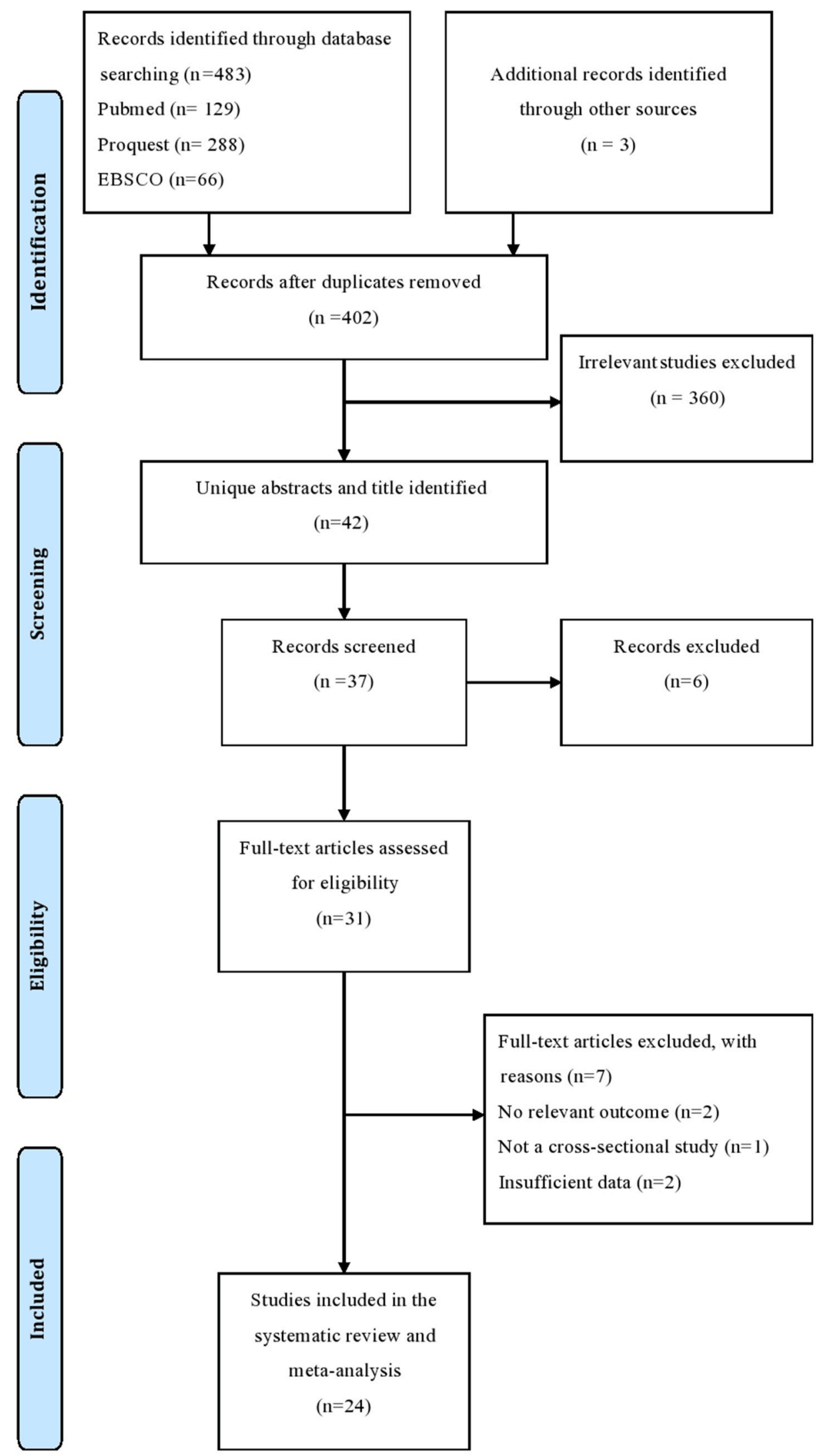

Fig. 1. The PRISMA flowcharts. 
Table 1

Systematic review of COVID-19 vaccination acceptance and correlated variables among global populations.

\begin{tabular}{|c|c|c|c|c|c|c|}
\hline First author, year & $\begin{array}{l}\text { Year of } \\
\text { study }\end{array}$ & Region & Study design & $\begin{array}{l}\text { Total } \\
\text { samples }\end{array}$ & Determinant factors (OR, 95\% CI) & NOS \\
\hline Al-Qerem et al. ${ }^{13}$ & 2021 & Middle Eastern & Cross sectional & 1,144 & $\begin{array}{l}\text { Older age }(2.42,1.22-4.79) \\
\text { High level of knowledge }(1.50,1.38-1.62)\end{array}$ & 7 \\
\hline Caserotti et al. ${ }^{14}$ & 2021 & Italy & Cross sectional & 2,267 & $\begin{array}{l}\text { Perceived risk }(4.86,3.53-6.74) \\
\text { Older age }(1.47,1.14-1.89)\end{array}$ & 7 \\
\hline Ditekemena et al. ${ }^{15}$ & 2021 & Republic of Congo & Cross sectional & 4,131 & $\begin{array}{l}\text { High income }(2.31,1.85-2.88) \\
\text { High education }(1.82,1.55-2.13) \\
\text { Perceived risk }(7.78,5.75-10.53) \\
\text { Chronic disease }(1.26,1.04-1.53)\end{array}$ & 6 \\
\hline Seale et al. ${ }^{16}$ & 2021 & Australia & Cross sectional & 1,420 & $\begin{array}{l}\text { Female }(1.40,1.10-1.80) \\
\text { Older age }(3.10,1.80-5.30) \\
\text { Chronic disease }(1.40,1.10-2.0)\end{array}$ & 7 \\
\hline Sallam et al. ${ }^{17}$ & 2021 & $\begin{array}{l}\text { Jordan, Kuwait, Saudi } \\
\text { Arabia }\end{array}$ & $\begin{array}{l}\text { Cross sectional (online } \\
\text { questionnaire) }\end{array}$ & 3,414 & $\begin{array}{l}\text { Male }(1.54,1.28-1.85) \\
\text { Chronic disease }(1.55,1.15-2.09)\end{array}$ & 7 \\
\hline Qattan et al. ${ }^{18}$ & 2021 & Saudi Arabia & Cross sectional & 736 & $\begin{array}{l}\text { Older age }(2.22,0.96-5.17) \\
\text { Male }(1.61,0.97-2.67)\end{array}$ & 7 \\
\hline Saied et al. ${ }^{19}$ & 2021 & Egypt & Cross sectional & 2,133 & Healthcare workers $(2.26,1.34-3.81)$ & 7 \\
\hline Alley et al. ${ }^{20}$ & 2021 & Australia & Cross sectional & 2,343 & $\begin{array}{l}\text { Female }(1.89,1.20-2.97) \\
\text { Chronic disease }(1.39,0.98-1.97)\end{array}$ & 7 \\
\hline Wong et al. ${ }^{21}$ & 2021 & Hongkong & A population-based survey & 1,200 & $\begin{array}{l}\text { Older age }(2.03,1.48-2.77) \\
\text { Chronic disease }(1.89,1.50-2.38) \\
\text { Perceived risk }(1.09,1.00-1.17) \\
\text { Perceived benefits of vaccination }(1.79 \text {, } \\
1.59-1.99) \\
\text { Trust in health system }(1.36,1.25-1.48)\end{array}$ & 7 \\
\hline Alqudeimat et al. ${ }^{22}$ & 2021 & Kuwait & Cross sectional & 2,368 & $\begin{array}{l}\text { Encountered with confirmed COVID-19 }(5.67 \text {, } \\
4.14-7.77) \\
\text { Flu vaccine during the previous season }(1.35 \text {, } \\
1.24-1.47)\end{array}$ & 6 \\
\hline $\begin{array}{l}\text { Gagneux- Brunon et al. } \\
\text { et al. }\end{array}$ & 2021 & French & Cross sectional & 1,554 & $\begin{array}{l}\text { Male }(2.21,1.69-2.90) \\
\text { Older age }(3.45,1.53-7.77) \\
\text { Flu vaccine during the previous season }(7.22 \text {, } \\
5.68-9.19) \\
\text { Fear about COVID-19 }(2.03,1.58-2.61) \\
\text { Perceived risk }(2.09,1.70-2.57)\end{array}$ & 6 \\
\hline Wang et al. (a) ${ }^{24}$ & 2021 & Hongkong & Cross sectional & 2,047 & $\begin{array}{l}\text { Married }(1.69,1.33-2.14) \\
\text { Flu vaccine during the previous season }(2.25 \text {, } \\
1.74-2.93)\end{array}$ & 7 \\
\hline Verger et al. ${ }^{25}$ & 2021 & France & Cross sectional & 2,678 & $\begin{array}{l}\text { Female }(1.22,0.96-1.55) \\
\text { Perceived risk }(3.01,2.38-3.79) \\
\text { Perceived benefits of vaccination }(1.57 \\
1.05-2.36)\end{array}$ & 5 \\
\hline Nzaji et al. ${ }^{26}$ & 2020 & Republic of Congo & Cross sectional & 613 & $\begin{array}{l}\text { Married }(1.25,0.85-1.83) \\
\text { Healtcare workers }(1.92,1.31-2.81) \\
\text { Encountered with confirmed COVID-19 }(8.83 \text {, } \\
1.18-66.04)\end{array}$ & 7 \\
\hline Lazarus et al. ${ }^{27}$ & 2020 & Global (19 countries) & Cross sectional & 13,426 & $\begin{array}{l}\text { Older age }(1.73,1.48-2.02) \\
\text { High education }(1.34,1.21-1.48) \\
\text { Trust in health system }(1.67,1.54-1.80)\end{array}$ & 5 \\
\hline Detoc et al. ${ }^{28}$ & 2020 & France & Cross sectional (online survey) & 3,259 & $\begin{array}{l}\text { Male }(1.71,1.42-2.06) \\
\text { Older age }(2.25,1.76-2.87) \\
\text { Healthcare workers }(1.57,1.33-1.86) \\
\text { Fear about COVID-19 }(2.09,1.75-2.49) \\
\text { Perceived risk }(1.83,1.54-2.16)\end{array}$ & 6 \\
\hline Bell et al. ${ }^{29}$ & 2020 & England & Cross sectional & 1,252 & High income $(2.53,1.67-3.83)$ & 6 \\
\hline Wang et al. (b) ${ }^{30}$ & 2020 & Hongkong, China & Cross sectional & 806 & $\begin{array}{l}\text { Male }(2.78,1.69-4.58) \\
\text { Encountered with confirmed COVID-19 (1.63, } \\
1.14-2.33) \\
\text { Flu vaccine during the previous season }(2.03 \text {, } \\
1.47-2.81)\end{array}$ & 7 \\
\hline Al-Mohaithef et al. ${ }^{31}$ & 2020 & Saudi Arabia & Cross sectional (web survey) & 992 & $\begin{array}{l}\text { Married }(1.57,1.20-2.06) \\
\text { Perceived risk }(2.48,1.11-3.95) \\
\text { Trust in the health system }(2.85,1.03-4.80)\end{array}$ & 7 \\
\hline Harapan et al. ${ }^{32}$ & 2020 & Indonesia & Cross sectional & 1,359 & $\begin{array}{l}\text { Female }(1.55,1.01-2.38) \\
\text { Older age }(2.10,1.04-4.23) \\
\text { Healthcare workers }(1.43,1.06-1.93)\end{array}$ & 7 \\
\hline Lin et al. ${ }^{33}$ & 2020 & China & Cross sectional & 3,541 & $\begin{array}{l}\text { Perceived benefits of vaccination ( } 3.14 \text {, } \\
2.05-4.83) \\
\text { Encountered with confirmed COVID-19 (1.65, } \\
1.31-2.09)\end{array}$ & 7 \\
\hline Malik et al. $^{34}$ & 2020 & $\mathrm{U} \cdot \mathrm{S}$ & Cross sectional & 672 & Older age $(1.81,0.99-3.29)$ & 5 \\
\hline Sherman et al. ${ }^{35}$ & 2020 & UK & Cross sectional & 1,500 & $\begin{array}{l}\text { Older age }(1.04,0.99-1.04) \\
\text { Perceived risk }(1.03,0.85-1.81) \\
\text { High level of knowledge }(1.08,1.04-1.39)\end{array}$ & 7 \\
\hline
\end{tabular}


Table 1 (continued)

\begin{tabular}{|c|c|c|c|c|c|c|}
\hline First author, year & $\begin{array}{l}\text { Year of } \\
\text { study }\end{array}$ & Region & Study design & $\begin{array}{l}\text { Total } \\
\text { samples }\end{array}$ & Determinant factors (OR, 95\% CI) & NOS \\
\hline Wang et al. (c) ${ }^{36}$ & 2020 & China & Cross sectional & 2,058 & $\begin{array}{l}\text { Male }(1.25,1.03-1.52) \\
\text { Married }(1.70,1.26-2.29) \\
\text { Perceived benefits of vaccination }(1.56 \text {, } \\
1.08-2.25)\end{array}$ & 5 \\
\hline Total samples & & & & 56,913 & & \\
\hline
\end{tabular}

Abbreviation: $\mathrm{CI}=$ confidence interval; OR = odds ratio; NOS, Newcastle-Ottawa Quality Assessment Scale.

opinions, and safety issues based on widespread misconceptions, such as the connection between vaccines and autism, brain injury, and other disorders, according to various reports. ${ }^{10}$ Regrettably, there have been inadequate research undertaken in order to determine the global population's attitudes toward vaccination. No previously published work has been analyzed by meta-analysis to our knowledge. The findings of this study may help the government figure out the important way to execute COVID-19 mass vaccination programs.

\section{Materials and methods}

\subsection{Study design and research sample}

To assess current articles related to the acceptance of COVID-19 vaccination and correlated variables, a systematic review and metaanalysis studies were conducted. The preferred reporting items for systematic reviews and meta-analyses (PRISMA) guideline was followed in this study. ${ }^{11}$ There are three databases, i.e. ProQuest, PubMed, and EBSCO were used to search for relevant articles published between January 2020 and March 2021. In this research, the acceptance of COVID-19 vaccine was the dependent variable. The independent variables were the determinant factors of COVID-19 vaccine acceptance.

\subsection{Research procedure}

The keywords used to search related articles in ProQuest, PubMed, and EBSCO between January 2020 and March 2021 were: COVID-19 OR Coronavirus AND Vaccine AND Acceptance. The included articles limited to original or research articles, with English texts and with human as study subjects. The inclusion criteria included study on the acceptance of COVID-19 vaccine and related factors with study design of cross sectional. The study exclusion criteria included full text version is unavailable, unrelated topics or subjects, and data in publications that could not be extracted or used for further review. The Newcastle-Ottawa Quality Assessment Scale (NOS) modified for cross-sectional study was used to evaluate the articles' quality. 0-3, 4-6, and 7-9 were used to categorize articles into poor, medium, and high quality categories. ${ }^{12}$ The PRISMA flowcharts were used to illustrate the steps involved in finding research articles (Fig. 1).

\subsection{Data analysis}

For further data analysis, the Pooled Odds Ratio (POR) of the effect size of each risk factor from the derived data was determined with a confidence degree of $95 \%$. The heterogeneity was calculated using the $\mathrm{I}^{2}$ formula, and $\mathrm{I}^{2}>50 \%$ indicated that there was heterogeneity between studies. If the result was heterogeneous, the random effect model was used, and if the result was homogeneous, the fixed effect model was used. Furthermore, the findings were viewed as forest plots, and publication bias was assessed using Egger's and Begg's tests. The $p>0.05$ results from the two tests revealed that there was no publication bias among the studies. For lower middle income countries (LMICs), restricted-maximum likelihood random effects meta-regression was used to examine the role of covariate. STATA 16.0 was used for all data processing and analysis.

\section{Results}

This systematic review study included 24 recent studies conducted to the acceptance of COVID-19 vaccination and related factors (Table 1). The total sample from the included studies was 56,913 participants. ${ }^{13-36}$

Table 1 is based on a synthesis of studies correlated variables for acceptance of COVID-19 vaccination, including 24 cross sectional studies. This study found factors contributing to acceptance of COVID19 vaccination included older age, male, female, married, high education, high income, healthcare workers, chronic diseases, high level of knowledge, perceived risk, perceived benefits, fear about COVID-19, encountered with COVID-19, flu vaccine during the previous season and trust in health system.

Meta-estimate of COVID-19 vaccination acceptance and correlated variables among global populations (Table 2 and Fig. 2). Table 2 and Fig. 2 showed high income has the highest Pooled Odds Ratio (POR, 95\% CI) $(2.36,1.94-2.87)$, followed by encountered with COVID-19 $(2.34$, 1.98-2.76), fear about COVID-19 (2.07, 1.79-2.39), perceived benefits (1.81, 1.61-2.00), flu vaccine during the previous season (1.69, 1.57-1.82), healthcare workers $(1.62,1.42-1.85)$, male (1.61, 1.47-1.78), married (1.59, 1.38-1.83), perceived risk (1.52, 1.43-1.62), trust in health system $(1.52,1.44-1.61)$, chronic diseases (1.47, 1.31-1.65]), and high education (1.46, 1.34-1.59), high level of knowledge (1.39, 1.29-1.49), female (1.39, 1.19-1.61]), and older age (1.07, 1.05-1.10) with COVID-19 vaccination acceptance. The heterogeneity calculation showed homogenous among studies in high income, fear about COVID-19, healthcare workers, married, chronic diseases, and female $\left(\mathrm{I}^{2} \leq 50 \%\right)$.

The results of Egger's and Begg's test to assess bias among studies included (Table 3). Table 3 showed that based on Egger's and Begg's test result ( $p>0.05$ ), related factors of older age, male, female, married, high education, high income, healthcare workers, chronic diseases, high level of knowledge, perceived risk, perceived benefits, fear about COVID-19, encountered with COVID-19, flu vaccine during the previous season and trust in health system had no publication bias among studies combined.

The association between LMICs and COVID-19 vaccine acceptance based on meta-regression (Fig. 3). Fig. 3 showed that the association between LMICs and decreased COVID-19 vaccine acceptance $(\mathrm{p}=0.02)$. This analysis confirmed the COVID-19 vaccine acceptance may vary across these country types.

\section{Discussion}

Our results found high income had high acceptance of COVID-19 vaccination. The acceptance rate rises with economic status. A study highlighted the importance of community confidence in vaccine uptake and found a scarcity of studies in low and middle-income households on vaccine uptake based on community trust. ${ }^{37} \mathrm{~A}$ higher willingness to receive COVID-19 vaccination was correlated with a higher income level, likely due to better access to high-quality information, such as through better television channels and/or through communication with people living abroad in COVID-19-affected countries, and/or because such people tend to live in towns where the virus is more prevalent. ${ }^{15}$

Encountered with COVID-19, fear of COVID-19 and perceived risk 
Table 2

Meta-estimate of COVID-19 vaccination acceptance and correlated variables among global populations.

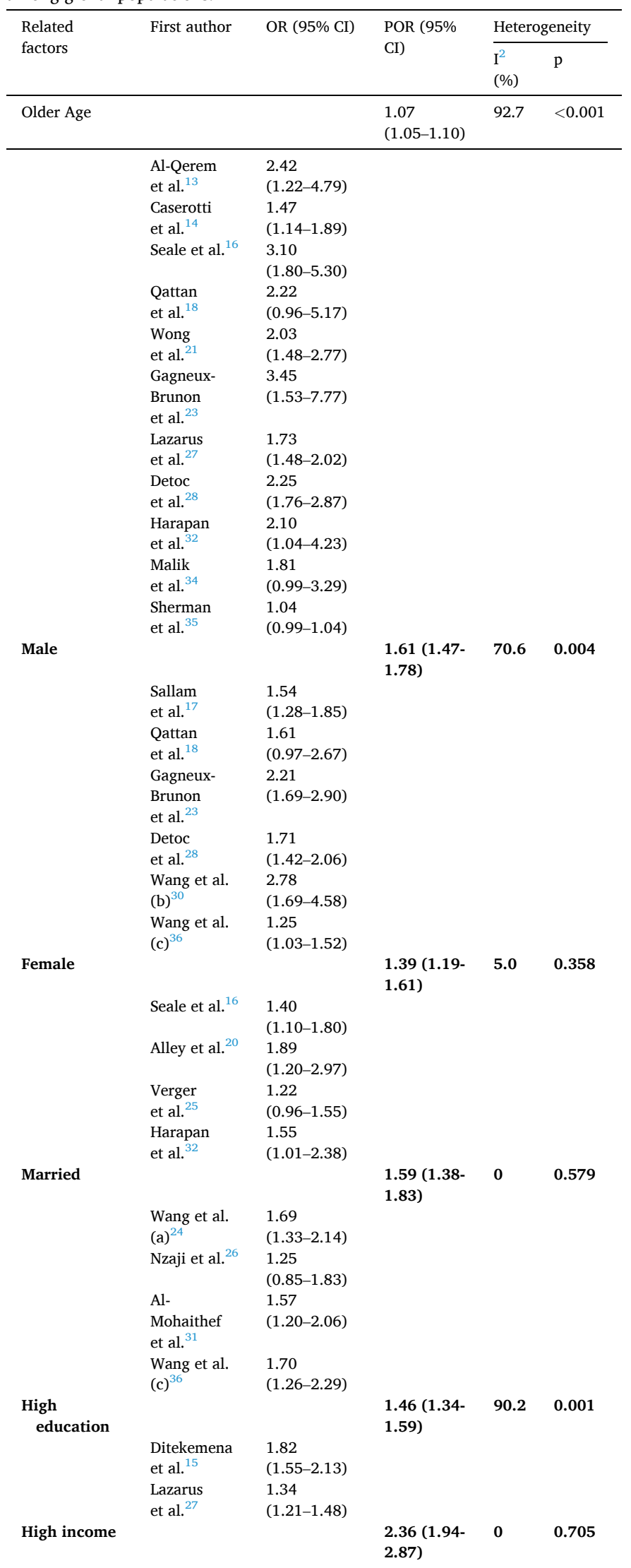

Table 2 (continued)

\begin{tabular}{|c|c|c|c|c|c|}
\hline \multirow{2}{*}{$\begin{array}{l}\text { Related } \\
\text { factors }\end{array}$} & \multirow[t]{2}{*}{ First author } & \multirow[t]{2}{*}{ OR $(95 \% \mathrm{CI})$} & \multirow{2}{*}{$\begin{array}{l}\text { POR }(95 \% \\
\text { CI) }\end{array}$} & \multicolumn{2}{|c|}{ Heterogeneity } \\
\hline & & & & $\begin{array}{l}\mathrm{I}^{2} \\
(\%)\end{array}$ & $\mathrm{p}$ \\
\hline & $\begin{array}{l}\text { Ditekemena } \\
\text { et al. }{ }^{15} \\
\text { Bell et al. }^{29}\end{array}$ & $\begin{array}{l}2.31 \\
(1.85-2.88) \\
2.53 \\
(1.67-3.83)\end{array}$ & & & \\
\hline \multirow[t]{4}{*}{$\begin{array}{l}\text { Healthcare } \\
\text { workers }\end{array}$} & & & $\begin{array}{l}1.62(1.42- \\
1.85)\end{array}$ & 3.9 & 0.373 \\
\hline & Saied et al. ${ }^{19}$ & $\begin{array}{l}2.26 \\
(1.34-3.81)\end{array}$ & & & \\
\hline & Nzaji et al. ${ }^{26}$ & $\begin{array}{l}1.92 \\
(1.31-2.81)\end{array}$ & & & \\
\hline & 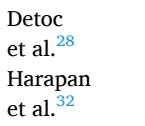 & $\begin{array}{l}1.57 \\
(1.33-1.86) \\
1.43 \\
(1.06-1.93)\end{array}$ & & & \\
\hline \multirow[t]{6}{*}{$\begin{array}{l}\text { Chronic } \\
\text { disease }\end{array}$} & & & $\begin{array}{l}1.47(1.31- \\
1.65)\end{array}$ & 45.4 & 0.120 \\
\hline & $\begin{array}{l}\text { Ditekemena } \\
\text { et al. }{ }^{15}\end{array}$ & $\begin{array}{l}1.26 \\
(1.04-1.53)\end{array}$ & & & \\
\hline & Seale et al. ${ }^{16}$ & $\begin{array}{l}1.40 \\
(1.10-2.000\end{array}$ & & & \\
\hline & $\begin{array}{l}\text { Sallam } \\
\text { et al. }^{17}\end{array}$ & $\begin{array}{l}1.55 \\
(1.15-2.09)\end{array}$ & & & \\
\hline & Alley et al. ${ }^{20}$ & $\begin{array}{l}1.39 \\
(0.98-1.97)\end{array}$ & & & \\
\hline & $\begin{array}{l}\text { Wong } \\
\text { et al. }{ }^{21}\end{array}$ & $\begin{array}{l}1.89 \\
(1.50-2.38)\end{array}$ & & & \\
\hline \multirow[t]{3}{*}{$\begin{array}{r}\text { High level of } \\
\text { knowledge }\end{array}$} & & & $\begin{array}{l}1.39(1.29- \\
1.49)\end{array}$ & 93.4 & $<0.001$ \\
\hline & $\begin{array}{l}\text { Al-Qerem } \\
\text { et al. }{ }^{13}\end{array}$ & $\begin{array}{l}1.50 \\
(1.38-1.62)\end{array}$ & & & \\
\hline & $\begin{array}{l}\text { Sherman } \\
\text { et al. }\end{array}$ & $\begin{array}{l}1.08 \\
(1.04-1.39)\end{array}$ & & & \\
\hline \multirow[t]{13}{*}{$\begin{array}{l}\text { Perceived } \\
\text { risk }\end{array}$} & & & $\begin{array}{l}1.52(1.43- \\
1.62)\end{array}$ & 97.5 & $<0.001$ \\
\hline & $\begin{array}{l}\text { Caserotti } \\
\text { et al. }{ }^{14}\end{array}$ & $\begin{array}{l}4.86 \\
(3.53-6.74)\end{array}$ & & & \\
\hline & $\begin{array}{l}\text { Ditekemena } \\
\text { et al. }{ }^{15}\end{array}$ & $\begin{array}{l}7.78 \\
(5.75-10.53)\end{array}$ & & & \\
\hline & Wong & 1.09 & & & \\
\hline & et $\mathrm{al}^{21}$ & $(1.00-1.17)$ & & & \\
\hline & Gagneux- & 2.09 & & & \\
\hline & $\begin{array}{l}\text { Brunon } \\
\text { et al. }{ }^{23}\end{array}$ & $(1.70-2.57)$ & & & \\
\hline & $\begin{array}{l}\text { Verger } \\
\text { et al. }^{25}\end{array}$ & $\begin{array}{l}3.01 \\
(2.38-3.79)\end{array}$ & & & \\
\hline & Detoc & 1.83 & & & \\
\hline & et al. ${ }^{28}$ & $(1.54-2.16)$ & & & \\
\hline & $\mathrm{Al}-$ & 2.48 & & & \\
\hline & $\begin{array}{l}\text { Mohaithef } \\
\text { et al. }{ }^{31}\end{array}$ & (1.11-3.95) & & & \\
\hline & $\begin{array}{l}\text { Sherman } \\
\text { et al. }\end{array}$ & $\begin{array}{l}1.03 \\
(0.85-1.81)\end{array}$ & & & \\
\hline \multirow[t]{6}{*}{$\begin{array}{r}\text { Perceived } \\
\text { benefits }\end{array}$} & & & $\begin{array}{l}1.81(1.64- \\
2.00)\end{array}$ & 59.9 & 0.058 \\
\hline & $\begin{array}{l}\text { Wong } \\
\text { et al. }^{21}\end{array}$ & $\begin{array}{l}1.79 \\
(1.59-1.99)\end{array}$ & & & \\
\hline & Verger & 1.57 & & & \\
\hline & et $\mathrm{al}^{25}$ & $(1.05-2.36)$ & & & \\
\hline & Lin et al. ${ }^{33}$ & $\begin{array}{l}3.14 \\
(2.05-4.83)\end{array}$ & & & \\
\hline & $\begin{array}{l}\text { Wang et al. } \\
\text { (c) }\end{array}$ & $\begin{array}{l}1.56 \\
(1.08-2.25)\end{array}$ & & & \\
\hline \multirow[t]{4}{*}{$\begin{array}{l}\text { Fear about } \\
\text { COVID-19 }\end{array}$} & & & $\begin{array}{l}2.07(1.79- \\
2.39)\end{array}$ & 0 & 0.852 \\
\hline & Gagneux- & 2.03 & & & \\
\hline & $\begin{array}{l}\text { Brunon } \\
\text { et al. }\end{array}$ & $(1.58-2.61)$ & & & \\
\hline & $\begin{array}{l}\text { Detoc } \\
\text { et } \text { al. }^{28}\end{array}$ & $\begin{array}{l}2.09 \\
(1.75-2.49)\end{array}$ & & & \\
\hline $\begin{array}{l}\text { Encountered } \\
\text { with }\end{array}$ & & & $\begin{array}{l}2.34(1.98- \\
2.76)\end{array}$ & 93.3 & $<0.001$ \\
\hline
\end{tabular}


Table 2 (continued)

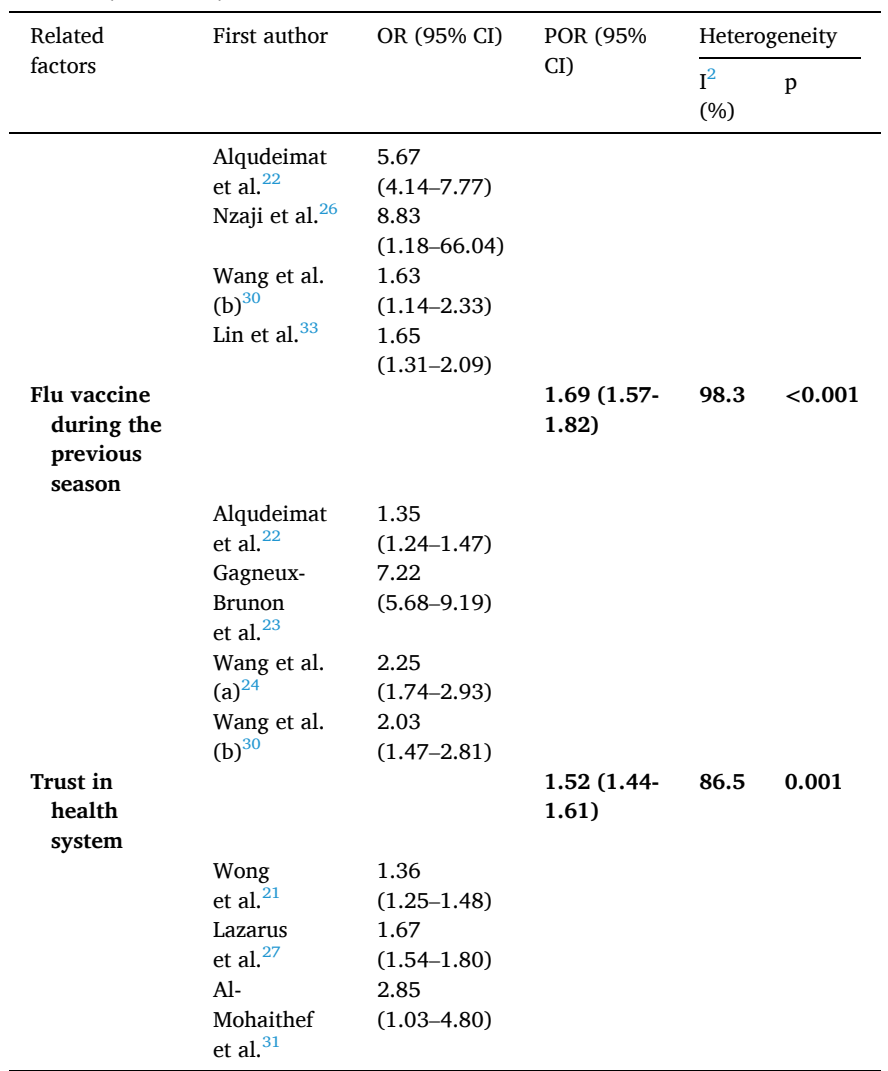

Abbreviation: $\mathrm{CI}=$ confidence interval; $\mathrm{OR}=$ odds ratio; $\mathrm{POR}=$ Pooled odds ratio; $\mathrm{I}^{2}>50 \%$, heterogeneity.

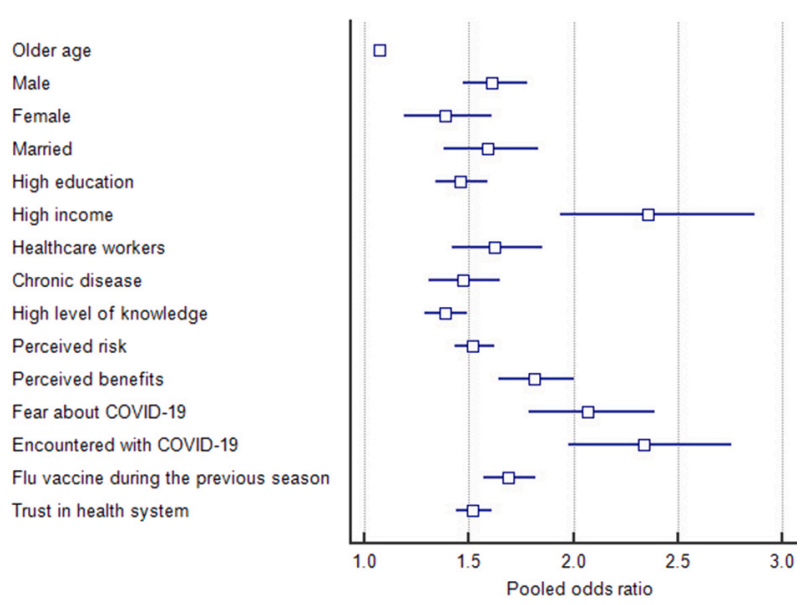

Fig. 2. Forest plots of COVID-19 vaccination acceptance and correlated variables among global populations.

have found to be positively correlated with vaccine acceptance in this study. Previous studies in Asia have shown that a positive attitude toward vaccination is linked to a perception of risk or fear about COVID19 . $^{38-40}$ Another study showed that a high perceived risk was related to COVID-19 vaccine acceptance among Saudi Arabian community members and Congo healthcare staff. ${ }^{26,31}$ As a consequence, it is crucial to boost community expectations of risk. Low risk perception can be linked to vaccine acceptance, as well as social distancing and other community health defensive measures. These associations may be complicated; for example, a person who practices social distancing strategies can believe their risk is low but still wants to get vaccinated.
Table 3

The results of Egger's and Begg's test to assess bias among studies included.

\begin{tabular}{lll}
\hline \multirow{2}{*}{ Related factors } & \multicolumn{2}{l}{ Study bias } \\
\cline { 2 - 3 } & Egger's test & Begg's test \\
\hline Older age & 0.925 & 0.139 \\
Male & 0.269 & 0.573 \\
Female & 0.137 & 0.052 \\
Married & 0.159 & 0.174 \\
High education & 0.112 & 0.317 \\
Low income & 0.115 & 0.317 \\
Healthcare workers & 0.304 & 0.174 \\
Chronic diseases & 0.804 & 1.000 \\
High level of knowledge & 0.811 & 0.317 \\
Perceived risk & 0.577 & 0.458 \\
Perceived benefits & 0.740 & 0.497 \\
Fear about COVID-19 & 0.160 & 0.227 \\
Encountered with COVID-19 & 0.051 & 0.174 \\
Flu vaccine during the previous season & 0.280 & 1.000 \\
Trust in health system & 0.767 & 0.602
\end{tabular}

$p>0.05$, no publication bias.

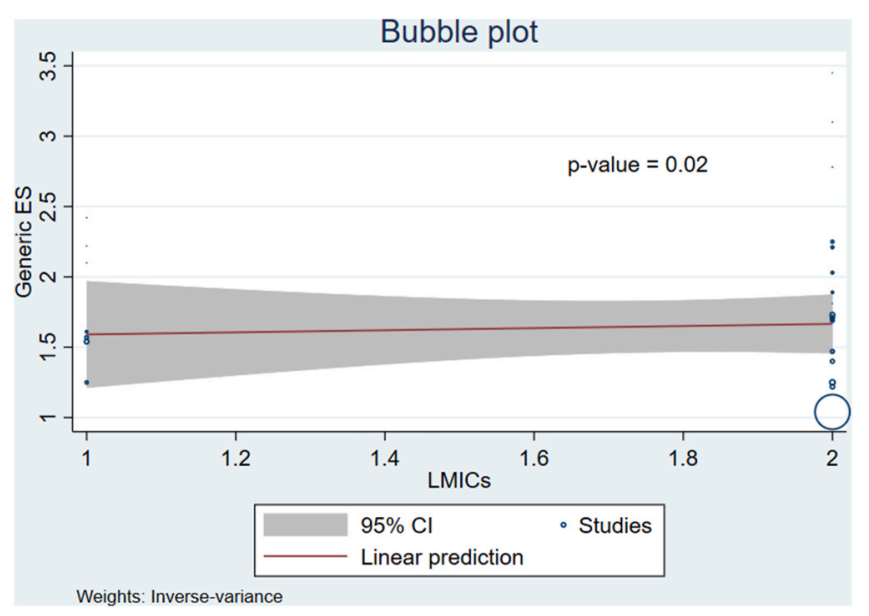

Fig. 3. The association between LMICs and COVID-19 vaccine acceptance based on meta-regression.

Vaccination intention is strongly influenced by perceived benefits. Perceived advantages have been found to be determinant factors in some studies. ${ }^{21,25}$ In the context of vaccination, perceived benefits are characterized as a person's attitudes toward vaccination. It's important to have public health intervention programs that concentrate on changing people's perceptions of vaccination's benefits while also removing the obstacles that have been identified.

According to the findings of this report, there is a correlation between influenza vaccination during the past season and COVID-19 vaccination acceptance. Related positively flu vaccination during the past season to COVID-19 vaccine acceptance. ${ }^{24,30}$ COVID-19 and seasonal influenza are likely to co-circulate during the winter of 2020-2021. Healthcare staff in France are advised to get vaccinated for the flu season. Patients with concomitant flu and COVID-19 can have poorer outcomes than patients with COVID-19 alone, so lowering the risk of coinfections in susceptible patients is important.

Healthcare staff were more enthusiastic about a COVID-19 vaccine than non-healthcare staff, according to our results. In previous research, self-protection and a willingness to protect families, friends, and patients were the driving factors behind healthcare staff getting vaccinated. ${ }^{41,42}$ Since healthcare staff have a more in-depth understanding of COVID-19, they will be more likely to protect themselves and not spread the virus to their family members. As a result, they could be more likely to consider the vaccine than those who work in non-medical fields.

Sex and married were also found to be positively correlated with 
vaccine acceptance in this study. Previous studies have shown that men, women, and married people are more likely to support immediate pandemic vaccination. ${ }^{17,24,27}$ This may be due to everyone at risk in the gender group and marital status. Older people agreed to be vaccinated in our report. This may be because the belief that older adults and people with severe comorbidities or chronic diseases are more vulnerable to COVID-19's negative effects can cause a lot of anxiety among the elderly. ${ }^{43}$

Individuals with university/higher levels of education recorded having a substantially higher level of knowledge about COVID-19 vaccine acceptance. Related scenarios were observed in previous studies, showing that people with a higher educational experience learned more about COVID-19. ${ }^{13,35}$ It's likely that more informed people are more aware of and caring about their health and well-being as a result of improved access to more media sources, as well as becoming more interested in life activities that may affect them.

Participants' confidence in the health-care system was discovered to be a major indicator of their ability to use the COVID-19 vaccine. In response to the present situation, a low confidence in the health system could put community health at risk. The application of preventive health services like vaccination has been linked to a higher level of confidence in the health system. ${ }^{44,45}$

This meta-analysis study has a number of limitations. Four articles seemed to be suitable for inclusion in this meta-analysis, but they lacked adequate evidence and had results that were insignificant for data estimation. This problem will exacerbate the risk of selection bias.

The results show that health departments should implement urgent health promotion services and disseminate more reliable information. Governments should take action to ensure that people have enough information, have healthy attitudes, and have positive opinions about COVID-19 vaccines.

\section{Conclusion}

This study results showed the related factors for COVID-19 vaccination acceptance, high income has the highest odd ratio, followed by encountered with COVID-19, fear about COVID-19, perceived benefits, flu vaccine during the previous season, healtcare workers, male, married, perceived risk, trust in health system, chronic diseases, high education, high level of knowledge, female, and older age. The heterogeneity calculation showed homogenous among studies in low income, fear about COVID-19, healthcare workers, married, chronic diseases, and female. The findings of this study may help the government figure out the best way to implement COVID-19 mass vaccination programs.

\section{Funding/ Financial Support}

This study obtained no particular support from public, private, or non-profit funding agencies.

\section{Acknowledgments}

The authors would like to express their gratitude to Riyani Betri Novialita, MA, for her assistance in data collection.

\section{References}

1 Centers for Disease Control and Prevention. Certain medical conditions and risk for severe COVID-19 Illness [Last cited March 30, 2021]. Available from: https://www. cdc.gov/coronavirus/2019-ncov/need-extraprecautions/people-with-medical-co nditions.html; 2021.

2 Nicola M, Alsafi Z, Sohrabi C, et al. The socio-economic implications of the coronavirus pandemic (COVID-19): a review. Int J Surg. 2020;78:185-193.

3 Tregoning JS, Brown ES, Cheeseman HM, et al. Vaccines for COVID-19. Clin Exp Immunol. 2020;202(2):162-192.
4 Shrotri M, Swinnen T, Kampmann B, Parker EPK. An interactive website tracking COVID-19 vaccine development. Lancet Glob Health. 2021;S2214-109X(21), 0004300047.

5 Chen D, Xu W, Lei Z, et al. Recurrence of positive SARS-CoV-2 RNA in COVID-19: a case report. Int J Infect Dis. 2020;93:297-299.

6 SeyedAlinaghi S, Oliaei S, Kianzad S, et al. Reinfection risk of novel coronavirus (COVID-19): a systematic review of current evidence. World J Virol. 2020;9(5): 79-90.

7 Cárdenas G, Soto-Hernández JL, Díaz-Alba A, et al. Neurological events related to influenza A (H1N1) pdm09. Influenza Other Respir Viruses. 2014;8(3):339-346.

8 Ada G. Vaccines and vaccination. N Engl J Med. 2001;345(14):1042-1053.

9 Geoghegan S, O'Callaghan KP, Offit PA. Vaccine safety: myths and misinformation. Front Microbiol. 2020;11:372.

10 McKee C, Bohannon K. Exploring the reasons behind parental refusal of vaccines. J Pediatr Pharmacol Therapeut. 2016;21(2):104-109.

11 Liberati A, Altman DG, Tetzlaff J, et al. The PRISMA statement for reporting systematic reviews and meta-analyses of studies that evaluate healthcare interventions:explanation and elaboration. BMJ. 2009;339:b2700.

12 Wells GA, Shea B, O'Connell D, et al. The Newcastle-Ottawa Scale (NOS) for assessing the quality of nonrandomised studies in meta-analyses [Last cited Feb 28, 2021]. Available from http://www.ohri.ca/programs/clinical_epidemiology/oxford. asp; 2009.

13 Al-Qerem WA, Jarab AS. COVID-19 vaccination acceptance and its associated factors among a middle eastern population. Front Public Health. 2021;9:632914.

14 Caserotti M, Girardi P, Rubaltelli E, Tasso A, Lotto L, Gavaruzzi T. Associations of COVID-19 risk perception with vaccine hesitancy over time for Italian residents. Soc Sci Med. 2021;272:113688.

15 Ditekemena JD, Nkamba DM, Mutwadi A, et al. COVID-19 vaccine acceptance in the democratic republic of Congo: a cross-sectional survey. Vaccines. 2021;9(2):153

16 Seale H, Heywood AE, Leask J, et al. Examining Australian public perceptions and behaviors towards a future COVID-19 vaccine. BMC Infect Dis. 2021;21:120.

17 Sallam M, Dababseh D, Eid H, et al. High rates of COVID-19 vaccine hesitancy and its association with conspiracy beliefs: a study in Jordan and Kuwait among other arab countries. Vaccines. 2021;9(1):42.

18 Qattan AMN, Alshareef N, Alsharqi O, Al Rahahleh N, Chirwa GC, Al-Hanawi MK. Acceptability of a COVID-19 vaccine among healthcare workers in the kingdom of Saudi arabia. Front Med. 2021;8:644300.

19 Saied SM, Saied EM, Kabbash IA, Abdo SAE. Vaccine hesitancy: beliefs and barriers associated with COVID-19 vaccination among Egyptian medical students. $J$ Med Virol. 2021;2021:1-12.

20 Alley SJ, Stanton R, Browne M, et al. As the pandemic progresses, how does willingness to vaccinate against COVID-19 evolve? Int J Environ Res Publ Health. 2021;18(2):797.

21 Wong MCS, Wong ELY, Huang J, et al. Acceptance of the COVID-19 vaccine based on the health belief model: a population-based survey in Hong Kong. Vaccine. 2021;39 (7):1148-1156.

22 Alqudeimat Y, Alenezi D, AlHajri B, et al. Acceptance of a COVID-19 vaccine and its related determinants among the general adult population in Kuwait. Med Princ Pract. 2021;2021:1-23.

23 Brunon GA, Detoc M, Bruel S, et al. Intention to get vaccinations against COVID-19 in French healthcare workers during the first pandemic wave: a cross-sectional survey. J Hosp Infect. 2021;108:168-173.

24 Wang K, Wong EL, Ho KF, et al. Change of willingness to accept COVID-19 vaccine and reasons of vaccine hesitancy of working people at different waves of local epidemic in Hong Kong, China: repeated cross-sectional surveys. Vaccines. 2021;9(1): 62.

25 Verger P, Scronias D, Dauby N, et al. Attitudes of healthcare workers towards COVID19 vaccination: a survey in France and French-speaking parts of Belgium and Canada, 2020. Euro Surveill. 2021;26(3):2002047.

26 Nzaji MK, Ngombe LK, Mwamba GN, et al. Acceptability of vaccination against COVID-19 among healthcare workers in the democratic republic of the Congo. Pragmatic Observational Res. 2020;11:103-109.

27 Lazarus JV, Ratzan SC, Palayew A, et al. A global survey of potential acceptance of a COVID-19 vaccine. Nat Med. 2021;27(2):225-228.

28 Detoc M, Bruel S, Frappe P, Tardy B, Botelho-Nevers E, Gagneux-Brunon A. Intention to participate in a COVID-19 vaccine clinical trial and to get vaccinated against COVID-19 in France during the pandemic. Vaccine. 2020;38(45):7002-7006.

29 Bell S, Clarke R, Mounier-Jack S, Walker JL, Paterson P. Parents' and guardians views on the acceptability of a future COVID-19 vaccine: a multi-methods study in England. Vaccine. 2020;38(49):7789-7798.

30 Wang K, Wong ELY, Ho KF, et al. Intention of nurses to accept coronavirus disease 2019 vaccination and change of intention to accept seasonal influenza vaccination during the coronavirus disease 2019 pandemic: a cross-sectional survey. Vaccine. 2020;38(45):7049-7056.

31 Al-Mohaithef M, Padhi BK. Determinants of COVID-19 vaccine acceptance in Saudi arabia: a web-based national survey. J Multidiscip Healthc. 2020;13:1657-1663.

32 Harapan H, Wagner AL, Yufika A, et al. Acceptance of a COVID-19 vaccine in southeast Asia: a cross-sectional study in Indonesia. Front Public Health. 2020;8:381.

33 Lin Y, Hu Z, Zhao Q, Alias H, Danaee M, Wong LP. Understanding COVID-19 vaccine demand and hesitancy: a nationwide online survey in China. PLoS Neglected Trop Dis. 2020;14(12), e0008961.

34 Malik AA, McFadden SM, Elharake J, Omer SB. Determinants of COVID-19 vaccine acceptance in the US. EClinicalMedicine. 2020;26:100495.

35 Sherman SM, Smith LE, Sim J, et al. COVID-19 vaccination intention in the UK: results from the COVID-19 vaccination acceptability study (CoVAccS), a nationally representative cross-sectional survey. Hum Vaccines Immunother. 2020;2020:1-10. 
36 Wang J, Jing R, Lai X, et al. Acceptance of COVID-19 vaccination during the COVID19 pandemic in China. Vaccines. 2020;8(3):482.

37 Larson HJ, Clarke RM, Jarrett C, et al. Measuring trust in vaccination: a systematic review. Hum Vaccines Immunother. 2018;14(7):1599-1609.

38 Rajamoorthy Y, Radam A, Taib NM, et al. The relationship between perceptions and self-paid hepatitis B vaccination: a structural equation modeling approach. PLoS One. 2018;13, e0208402.

39 Rajamoorthy Y, Radam A, Taib NM, et al. Willingness to pay for hepatitis B vaccination in Selangor, Malaysia: a cross-sectional household survey. PLoS One. 2019;14, e0215125.

40 Sundaram N, Purohit V, Schaetti C, Kudale A, Joseph S, Weiss MG. Community awareness, use and preference for pandemic influenza vaccines in Pune, India. Hum Vaccines Immunother. 2015;11:2376-2388.
41 Vasilevska M, Ku J, Fisman DN. Factors associated with healthcare worker acceptance of vaccination: a systematic review and metaanalysis. Infect Control Hosp Epidemiol. 2014;35:699-708.

42 Nguyen TTM, Lafond KE, Nguyen TX, et al. Acceptability of seasonal influenza vaccines among health care workers in Vietnam in 2017. Vaccine. 2020;38: 2045-2050.

43 Dubey S, Biswas P, Ghosh R, et al. Psychosocial impact of COVID-19. Diabetes Metab Syndr. 2020;14(5):779-788.

44 Quinn SC, Jamison AM, An J, Hancock GR, Freimuth VS. Measuring vaccine hesitancy, confidence, trust and flu vaccine uptake: results of a national survey of White and African American adults. Vaccine. 2019;37(9):1168-1173.

45 Harris KM, Maurer J, Kellermann AL. Influenza vaccine - safe, effective, and mistrusted. N Engl J Med. 2010;363(23):2183-2185. 